\title{
RISK IN WATER SUPPLY SYSTEM CRISIS MANAGEMENT
}

\section{RYZYKO W ZARZĄDZANIU KRYZYSOWYM SYSTEMEM ZAOPATRZENIA W WODE}

\author{
Barbara Tchórzewska-Cieślak \\ Faculty of Civil and Environmental Engineering, Rzeszow University of Technology, \\ Wydział Budownictwa I Inżynierii Środowiska, Politechnika Rzeszowska, \\ Al. Powstańców Warszawy 6, 35-959 Rzeszów, Poland \\ e-mail: cbarbara@prz.rzeszow.pl
}

\begin{abstract}
Water supply system belongs to the so called critical infrastructure of cities, and it should be a priority task for waterworks and even for the local authorities to ensure the suitable level of its safety. This system is characterised by its continuous work and requires high reliability level for its operating as well as for its safety, it is unique and its particular elements have different functions and simultaneously they interact forming an integral whole. The main aim of this paper is to present problems associated with water supply system safety management in a crisis situation.
\end{abstract}

Keywords: water supply system, risk management

Streszczenie: System zaopatrzenia w wodę należy do tzw. infrastruktury krytycznej miast a jego bezpieczeństwo powinno mieć priorytetem dla przedsiębiorstw wodociągowych a nawet władz lokalnych. System ten charakteryzuje się praca ciągłą o wysokim wymaganym poziomie niezawodności i bezpieczeństwa, składa się $\mathrm{z}$ podsystemów, pełniących różne funkcje i stanowiących integralna całość. Głównym celem pracy jest przedstawienie problemu zarządzania bezpieczeństwem systemu zaopatrzenia w wodę $\mathrm{w}$ sytuacji kryzysowej.

Słowa kluczowe: system zaopatrzenia w wodę, zarządzanie ryzykiem 


\section{RISK IN WATER SUPPLY SYSTEM CRISIS MANAGEMENT}

\section{Introduction}

Civilization conditions cause increase in interest in problems connected with municipal systems safety management, especially when a critical situation occurs. Opinions on water supply system (WSS) safety change along with the progress of science and technology. Water supply system belongs to the so called critical infrastructure of cities, and it should be a priority task for waterworks and even for the local authorities to ensure the suitable level of its safety. This system is characterised by its continuous work and requires high reliability level for its operating as well as for its safety, it is unique and its particular elements have different functions and simultaneously they interact forming an integral whole. The leading measure describing the loss of safety in WSS is risk which combines the probability of undesirable event occurrence and the related consequences. The notion of risk was introduced to European law by virtue of the instruction 89/392/EWG from 1989 on the adaptation of the state members regulations concerning machines. Tersely speaking safety is defined as a state of system characterized by the lack of unacceptable risk. The WSS safety management is an operator managerial activity to establish the aims (counteraction against lack of water or its bad quality, threatening health of municipal water pipe users) and to supervise their accomplishment using processes, information resources in the given operating conditions, in compliance with the valid law and with economic justification. The special case of WSS safety management is system management in a crisis situation.

\section{Water supply system as an element of critical infrastructure}

In June 2004 the European Council asked to prepare an overall strategy for critical infrastructure protection. In December 2006 the European Commission presented a project (conclusion) of Council Directive on identification and designation of an European critical infrastructure and evaluation of needs to enhance its protection, in order to elaborate the European Program for Critical Infrastructure Protection (EPCIP) and 
a Critical Infrastructure Warning Information Network (CIWIN) [10]. A definition of critical infrastructure is the following: critical infrastructure means systems and functionally interconnected objects being part of these systems, including building objects, units, installations, services, key or state and citizens safety that also ensure the efficient functioning of state administration bodies, as well as institutions and businessmen $[9,10]$. Critical infrastructure comprises the following systems: energy and fuel supply, drinking water supply, communication and information network, financial, food supply, health care, transportation and communication, rescue, which ensure the continuity of public administration functioning, production, storage, usage of chemicals and radioactive substances, including pipelines with hazardous substances. A programme of critical infrastructure protection, that main purpose is to protect above mentioned infrastructure, should contain: procedures for critical infrastructure designation, identification of functionally essential elements of infrastructure, risk analysis based on the scenarios of serious threats, weak points analysis and potential consequences analysis [4,6], identification, selection and establishment of priority of the counteraction measures, dividing them into: permanent safety measures ( determining the necessary investments and measures for safety, access control, supporting and preventive measures, procedures of informing of crisis management threats, improving social awareness, trainings and information systems safety) and emergency safety measures, that are initiated depending on changes of threats risk level: elaborated critical infrastructure warning information network (e.g. multi barrier system [4]), emergency plans, e.g. alternative sources of water supply, water provided by means of water cart or bottled water [2,5], financial means securing and appointment of teams of experts to coordinate EPCIP implementation.

\section{The WSS safety management in crisis situation}

\subsection{Legal status}

The chapter XI of the Constitution of the Republic of Poland titled "Extraordinary Measures" defines situations of particular danger, in which ordinary constitutional measures are inadequate and a state of natural disaster may be introduced. A legislator defines the notion of a state of natural disaster as a natural disaster or a technological failure whose consequences threaten health of a high number of people, a great amount of 
assets or an environment in large area, and help and protection can be taken effectively only by using extraordinary measures, when different bodies and institutions, as well as special services and teams act under joint management. A state of natural disaster may be introduced to avoid the consequences of natural disasters (e.g. flood, draught, etc) or of technological failures having features of a natural disaster and to remove them. In the article 3 of the Act on State of Natural Disaster [8] the notion of natural disaster is defined as an event associated with the action of the forces of nature. Technological failure, however, according to this act, is a violent unforeseen damage or destruction of building object, technical unit or technical units system, causing a break in their usage or the loss of features. A disaster having enormous size is called a cataclysm, secondary effects of disasters are infectious diseases, epidemics, natural environment destruction [1,2]. The notion of a serious failure and a serious industrial failure was introduced by the act issued on 27 April 2001 titled Environment Protection Right. On 26 April 2007, the Act on Crisis Management was passed [7] (this act abolishes Act on State of Natural Disaster [8]), which defines a procedure which should be used when there are no conditions to introduce one of the constitutional extraordinary measures (The chapter XI of the Constitution). The act defines a crisis situation as a situation resulting from the hazard and leading, in consequence, to break or considerable damage of social bonds, with, at the same time, a serious disturbance in public institutions functioning, in such degree, however, that used measures necessary to ensure or restore safety do not justify the introduction any of the extraordinary measures given in article 228 section 1 of the Constitution of the Republic of Poland.

\subsection{Water supply in crisis situations}

In crisis situation drinking water which is supplied to water pipes in a required quantity should be taken, if possible, from the underground water intakes, the other intakes in those conditions become the reserve intakes. Water pipe should have the possibility to [3]: cut off given water intakes with the operational possibility to use the whole system or its fragments, e.g. water pipe network, water intake, transit water pipes, activate alternative water treatment technology (e.g. periodical dosage of active carbon in a powdery form), increase dosage of disinfecting agent, supply water bypassing Water Treatment Plant [5]. A required quantity of water provided from the reserve intakes should be treated in water treatment plants, mobile water treatment plants and special filters having 
the technological systems in which the removal of water pollution is possible. The minimum water pressure in water pipe network should be 0.1 $\mathrm{MPa}$ for the municipal water pipe and $0.06 \mathrm{MPa}$ for the rural water pipe. [2]. If water pipe is inactivated and in the areas without water pipe network, water is supplied from emergency wells. When a number of the emergency wells is too law or their layout is unfavourable one should predict water delivery by tanks or water- carts. Water pipes and emergency wells should be prepared to be supplied with energy from generating sets, possibly they should be equipped with generating sets having such power that will ensure the start of pumps and water supply during the limited deliveries. Fuel reserve should be enough for $400 \mathrm{hrs}$, however for not less than $200 \mathrm{hrs}$ of generating sets operating. Water requirement in crisis situation should be established for all the municipal water pipes and for villages without water pipe network. It should be assured from water pipes and emergency wells, and also from industrial intakes, if necessary. One can distinguish two kinds of water requirements in crisis situation [2]:

- necessary water quantity (for a few weeks time): population $15 \mathrm{dm}^{3} /$ person, day,

- minimum water quantity (for a few days time): population $7,5 \mathrm{dm}^{3} /$ person, day.

\subsection{Risk as an element of the WSS safety management}

The WSS safety management is conducted through risk analysis, and especially through [4]: risk identification, including identification of threats and consequences for possible representative emergency scenarios, risk evaluation (assessment), rules for dealing with risk financing. Risk identification generally means the analysis of risk factors, their sources, determination of the so called weak points and consequences (results) of their occurrence. The most often this analysis concerns the undesirable events, which can appear in system with determined probability "P" and cause determined losses "C", which can result in the loss of the WSS safety. These events can have a single (incidental) character, it can be a series of events or a single event triggering a series of next events (the so called domino effect), which in consequence can cause a crisis situation. A process of risk evaluation mainly lies in the determination (assessment) of its numerical value and the comparison with the accepted criteria values. The most popular scale of risk levels is the three level scale, according to the rule: tolerable risk $-\mathrm{r}_{\mathrm{T}}$, controlled risk $-\mathrm{r}_{\mathrm{K}}$, unacceptable risk $-\mathrm{r}_{\mathrm{N}}$. The assumption of the criteria values for the particular scale levels depends on 
many factors, including experts opinions, as well as the accepted method of risk assessment, e.g. 2,3,4 or 5 parameter matrix method [3]. The analysis of results, from the point of the possibility that a crisis situation will appear, can be carried out on the base of: percentage distribution of risk acc. to risk category (type), distribution of unacceptable risks, risk maps, i.e. distribution of tolerable, controlled and unacceptable risk, and an extent of acceptable risk as a sum of tolerable and controlled risks. The determination of the so called risk indicators $\left(\mathrm{Wr}_{\mathrm{ij}}\right)$ for all risk types. Risk $(\mathrm{r})$ is a function of three parameters: the probability $\mathrm{P}_{\mathrm{Si}}$ that $i$ representative emergency scenario $\mathrm{S}_{\mathrm{i}}$ occurs, the magnitude of losses $\mathrm{C}_{\mathrm{Si}}$ caused by $i$ representative emergency scenario $S_{i}$ and the consumers protection $\mathrm{O}_{\mathrm{Si}}$ against $i$ representative emergency scenario $\mathrm{S}_{\mathrm{i}}, \mathrm{r}=\mathrm{f}\left(\mathrm{P}_{\mathrm{Si}}, \mathrm{C}_{\mathrm{Si}}, \mathrm{O}_{\mathrm{Si}}\right)$ [4]. The formula to determine risk measure is the following:

$r=\frac{P_{S i} \cdot C_{S i}}{O_{S i}}$

where:

$\mathrm{S}_{\mathrm{i}}-i$ representative emergency scenario, described as a series of the successive undesirable events,

$\mathrm{P}_{\mathrm{Si}}$ - a point weight associated with the probability that $i$ representative emergency scenario $S_{i}$ will occur, according to the point weights: low -1 , medium - 2, high- 3 ,

$\mathrm{C}_{\mathrm{Si}}$ - a point weight associated with a magnitude of losses triggered by a representative emergency scenario $\mathrm{S}_{\mathrm{i}}$, according to the point weights: low -1, medium -2, high-3,

$\mathrm{O}_{\mathrm{Si}^{-}}$a point weight associated with the WSS protection against a representative emergency scenario $\mathrm{S}_{\mathrm{i}}$, according to the point weights: low -1, medium -2, high-3.

In this way we can obtain 27 possible risk values. The criteria values for the particular scale levels are the following: tolerable risk - $\mathrm{r}_{\mathrm{T}}$ : $[0,33 \div 2)$, controlled risk $r_{\mathrm{K}}:[2 \div 4)$, unacceptable risk $-\mathrm{r}_{\mathrm{N}}:[4 \div 9]$. Within the framework of Own Research in Faculty of Water Supply and Sewage Disposal in Rzeszow University of Technology, in accordance with a risk catalogue, the identification of risk of the five WSS subsystems $(j=1$ - water intake, $\mathrm{j}=2$ - water treatment, $\mathrm{j}=3$ - water pumping and storage, $\mathrm{j}=4$ - water transfer and $\mathrm{j}=5$ - water distribution) was performed, a number of risks contained within the assumed risk scale was calculated. Based on it the risk index $\mathrm{Wr}_{\mathrm{ij}}$ was calculated, which was presented in tab.1 
Table 1. Example of the different risk types analysis.

\begin{tabular}{|l|c|c|c|c|c|c|c|c|c|}
\hline \multirow{2}{*}{$\mathrm{j}$} & \multicolumn{3}{|c|}{ Number of risks for $i$ level } & $\sum_{\mathrm{KTj}}$ & $\sum \mathrm{r}_{\mathrm{NKTj}}$ & $\mathrm{Wr}_{\mathrm{Tj}}$ & $\mathrm{Wr}_{\mathrm{Kj}}$ & $\mathrm{Wr}_{\mathrm{Aj}}$ & $\mathrm{Wr}_{\mathrm{Nj}}$ \\
\cline { 2 - 11 } & $\mathrm{i}=1-\mathrm{r}_{\mathrm{Tj}}$ & $\mathrm{i}=2-\mathrm{r}_{\mathrm{Kj}}$ & $\mathrm{i}=3-\mathrm{r}_{\mathrm{Nj}}$ & & & & & & \\
\hline $\mathrm{j}=1$ & 6 & 3 & 1 & 9 & 10 & 0,60 & 0,30 & 0,90 & 0,10 \\
\hline $\mathrm{j}=2$ & 4 & 3 & 2 & 7 & 9 & 0,44 & 0,33 & 0,78 & 0,22 \\
\hline $\mathrm{j}=3$ & 3 & 2 & 1 & 5 & 6 & 0,50 & 0,33 & 0,83 & 0,17 \\
\hline $\mathrm{j}=4$ & 5 & 3 & 2 & 8 & 10 & 0,50 & 0,30 & 0,80 & 0,20 \\
\hline $\mathrm{j}=5$ & 7 & 5 & 3 & 12 & 15 & 0,47 & 0,33 & 0,80 & 0,20 \\
\hline
\end{tabular}

The following notions were assumed:

$\mathrm{Wr}_{\mathrm{ij}}$ - risk index for the $j$ WSS subsystem with scale $i$,

$\mathrm{Wr}_{\mathrm{Tj}}$ - tolerable risk index,

$\mathrm{Wr}_{\mathrm{Ki}}$ - controllable risk index,

$\mathrm{Wr}_{\mathrm{Nj}^{-}}$unacceptable risk index,

$\mathrm{Wr}_{\mathrm{Aj}}$ - acceptable risk index,

j- subsystem WSS $(j=1,2,3,4,5)$,

i-particular risk levels $\left(i=1\right.$ for $r_{T}, i=2$ for $r_{K}, i=3$ for $\left.r_{N}\right)$.

The particular risk index values $\mathrm{Wr}_{\mathrm{ij}}$ were calculated according to the following formulas:

- Tolerable risk index $\mathrm{Wr}_{\mathrm{Tj}}$ acc.to formula :

$W r_{T_{j}}=\frac{r_{T j}}{\sum_{i} r_{i j}}$

- Controllable risk index $\mathrm{Wr}_{\mathrm{Kj}}$ acc. to formula:

$W r_{K} j=\frac{r_{K} j}{\sum_{i} r_{i j}}$

$\sum_{i} r_{i j}=r_{T j}+r_{K}{ }_{j}+r_{N j}$

- Unacceptable risk index $\mathrm{Wr}_{\mathrm{Nj}}$ acc. to formula:

$$
W r_{N j}=\frac{r_{N j}}{\sum_{i} r_{r_{i j}}}
$$


- Acceptable risk index $\mathrm{Wr}_{\mathrm{Aj}}$ acc. to formula:

$\boldsymbol{W} \boldsymbol{r}_{\boldsymbol{A}}=\frac{\boldsymbol{r}_{\boldsymbol{A} j}}{\sum_{\boldsymbol{i}} \boldsymbol{r}_{\boldsymbol{r}_{\boldsymbol{i j}}}}$

$\boldsymbol{r}_{\boldsymbol{A}}=\boldsymbol{r}_{\boldsymbol{T} \boldsymbol{j}}+\boldsymbol{r}_{\boldsymbol{K}}$

$\mathrm{r}_{\mathrm{Aj}}$ - acceptable risk

\section{Conclusions}

Critical management of critical infrastructure is an important issue and requires the individual analysis for every type of infrastructure, including drinking water supply systems. In different crisis situations, e.g. flood, draught, earthquake, technological failure etc, there is always a problem to supply drinking water to people. Many times the lack of such provision can be a reason of serious diseases and even epidemics. Also the WSS itself can cause a crisis situation when different scenarios of the undesirable events, which can cause system operating unreliability, and in consequence, the loss of water consumers safety, occur. Therefore the development of the plans for drinking water supply in emergency, for different critical situations, as well as the detailed analysis of the risk of the possibility that the undesirable events in the WSS will occur, in order to develop a complex program of the system safety management, is so important.

Scientific work was financed from the measures for research in years 2007-2010, as a research project Nr N N523 376533 entitled “ Development of the methodology of analysis and assessment of risk of failure in water supply systems, with regard to water consumers safety. “

\section{References}

[1] Konieczny J.: Zarzqdzanie $w$ sytuacjach kryzysowych wypadkach $i$ katastrofach. Oficyna Wydawnicza „GARMOND”, Poznań Warszawa, 2001.

[2] Rak J., Kucharski B.: Zaopatrzenie $w$ wodę $w$ sytuacjach kryzysowych. Konferencja: KMPSP. Wydawnictwo Politechniki Koszalińskiej,. Koszalin-Łazy., s.268-279, 2004.

[3] Rak J., Tchórzewska-Cieślak B.: Review of matrix methods for risk assessment in water supply system. Wydawnictwo Instytutu 
Technicznego Wojsk Lotniczych. Journal of Konbin, t.1, z.1, s.67-76, 2006.

[4] Rak J., Tchórzewska-Cieślak B.: Metody analizy $i$ oceny ryzyka $w$ systemie zaopatrzenia $w$ wodę. Oficyna Wydawnicza Politechniki Rzeszowskiej. Rzeszów, 2005

[5] Tchórzewska-Cieślak B. Use of maintenance technique directed to reliability to manage risk connected with water supply system operation.

XIX Krajowa Konferencja i VII Międzynarodowa Konferencja "Zaopatrzenie w wodę jakość i ochrona wód". Poznań - Zakopane, t.2, s.631-638, 2006.

[6] Tchórzewska-Cieślak B.: Method of assessing of risk of failure in water supply system. European safety and reliability conference ESREL. Risk, reliability and societal safety. Taylor \& Francis, t.2, s.1535-1539, Norway, Stavanger 200.7

[7] Ustawa z dnia 26 kwietnia 2007 r. o zarządzaniu kryzysowym (Dz. U. 2007 r., Nr 89, poz. 590)

[8] Ustawa z dnia 18 kwietnia 2002 r. o stanie klęski żywiołowej (Dz.U. z 2002 r. Nr 62, poz. 558).

[9] ISO/IEC 27005. Zarządzanie ryzykiem bezpieczeństwa informacji.

[10] Wniosek Komisji Wspólnot Europejskich w sprawie rozpoznania i wyznaczania europejskiej infrastruktury krytycznej oraz oceny w zakresie zwiększania jej ochrony. KOM(2006) 787. 2206/0276 (CNS). 


\section{RYZYKO W ZARZĄDZANIU KRYZYSOWYM SYSTEMEM ZAOPATRZENIA W WODE}

\section{Wstęp}

Uwarunkowania cywilizacyjne powodują wzrost zainteresowania problematyką zarządzania bezpieczeństwem systemów komunalnych, szczególnie w przypadku zaistnienia sytuacji kryzysowej. Poglądy na bezpieczeństwo systemu zaopatrzenia $\mathrm{w}$ wodę (SZW) zmieniają się wraz $\mathrm{z}$ postępem nauki i techniki. System zaopatrzenia w wodę należy do tzw. infrastruktury krytycznej miast, a zapewnienie odpowiedniego poziomu jego bezpieczeństwa powinno być priorytetowym zadaniem przedsiębiorstw wodociągowych, a nawet władz lokalnych. Wiodącą miarą opisującą utratę bezpieczeństwa przez SZW jest ryzyko, które łączy w sobie prawdopodobieństwo wystąpienia zdarzenia niepożądanego i konsekwencje z nim związane. Pojęcie ryzyka zostało wprowadzone do prawa europejskiego na mocy dyrektywy 89/392/EWG z 1989 roku w sprawie dostosowania praw państw członkowskich dotyczących maszyn. Lapidarnie bezpieczeństwo definiuje się jako stan systemu charakteryzujący się brakiem nieakceptowanego ryzyka. Zarządzanie bezpieczeństwem SZW jest działalnością kierowniczą operatora polegającą na ustaleniu celów (przeciwdziałaniu brakowi dostawy wody lub jej złej jakości zagrażającej zdrowiu konsumentów korzystających $\mathrm{z}$ wodociagu publicznego) i powodzeniu ich realizacji $\mathrm{z}$ wykorzystaniem procesów, zasobów informacji $w$ danych warunkach eksploatacyjnych, zgodnie z obowiązującym prawem i racjonalnie ekonomicznie. Szczególnym przypadkiem zarządzania bezpieczeństwem SZW jest zarządzanie systemem w sytuacji kryzysowej.

\section{System zaopatrzenia w wodę jako element infrastruktury krytycznej}

W czerwcu 2004 roku Rada Europejska wezwała do przygotowania ogólnej strategii ochrony infrastruktury krytycznej. W grudniu 2006 Komisja Wspólnot Europejskich przedstawiła projekt (wniosek) Dyrektywy Rady w sprawie rozpoznania i wyznaczania europejskiej infrastruktury krytycznej oraz oceny potrzeb w zakresie zwiększania jej ochrony, w celu opracowania europejskiego programu ochrony infrastruktury krytycznej 
(EPOIK) i sieci ostrzegania o zagrożeniach dla infrastruktury krytycznej (SOZIK) [10]. Definicja infrastruktury krytycznej brzmi następująco: przez infrastrukturę krytyczna należy rozumieć systemy oraz wchodzące w ich skład powiązane ze sobą funkcjonalnie obiekty, w tym obiekty budowlane, urządzenia, instalacje, usługi kluczowe dla bezpieczeństwa państwa i jego obywateli oraz służące zapewnieniu sprawnego funkcjonowania organów administracji publicznej, a także instytucji i przedsiębiorców[9,10]. Infrastruktura krytyczna obejmuje systemy: zaopatrzenia w energie i paliwa, zaopatrzenia $\mathrm{w}$ wodę do spożycia, łączności i sieci teleinformatycznych, finansowe, zaopatrzenia w żywność, ochrony zdrowia, transportowe i komunikacyjne, ratownicze, zapewniające ciagłość działania administracji publicznej, produkcji, składowania, przechowywania i stosowania substancji chemicznych i promieniotwórczych, w tym rurociagi substancji niebezpiecznych. Program ochrony infrastruktury krytycznej, którego głównym celem jest ochrona $\mathrm{w} / \mathrm{w}$ infrastruktury powinien zawierać: procedury określania infrastruktury krytycznej, rozpoznanie istotnych funkcjonalnie elementów infrastruktury, analizę ryzyka opartego na scenariuszach poważnych zagrożeń, analizie słabych punktów oraz analizie potencjalnych skutków $[4,6]$, rozpoznanie, selekcja i ustalenie hierarchii ważności środków przeciwdziałania, z podziałem na: stałe środki bezpieczeństwa (określające niezbędne inwestycje i środki w dziedzinie bezpieczeństwa, kontroli dostępu, środków zabezpieczających i zapobiegawczych, procedur sygnalizowania zagrożeń zarządzania kryzysowego, podnoszenie świadomości społecznej, szkolenia oraz bezpieczeństwo systemów informacyjnych) i doraźne środki bezpieczeństwa, które uruchamia się $\mathrm{w}$ zależności od zmieniającego się poziomu ryzyka zagrożeń, opracowaną sieć ostrzegania o zagrożeniach dla infrastruktury krytycznej (np. system mulibariery [4])., plany awaryjne np. alternatywne źródła zaopatrzenia ludności w wodę, dowóz wody beczkowozami lub wody butelkowanej [2,5], zabezpieczenie środków finansowych oraz powołanie grup ekspertów w celu koordynacji wdrożenia EPOIK.

\section{Zarządzanie bezpieczeństwem SZW w sytuacji kryzysowej}

\subsection{Stan prawny}

Rozdział XI „Stany nadzwyczajne” Konstytucji Rzeczypospolitej Polskiej określa sytuacje szczególnych zagrożeń, w których zwykłe środki konstytucyjne są niewystarczające i może być wprowadzony wówczas stan 
klęski żywiołowej. Ustawodawca określa pojęcie stanu klęski żywiołowej, rozumianej jako katastrofę naturalną lub awarię techniczną, których skutki zagrażają zdrowiu dużej liczby osób, mieniu w wielkich rozmiarach albo środowisku na znacznym obszarze, a pomoc i ochrona mogą być skutecznie podjęte tylko przy zastosowaniu nadzwyczajnych środków, we współdziałaniu różnych organów i instytucji oraz specjalistycznych służb i formacji działających pod jednolitym kierownictwem. Stan klęski żywiołowej może być wprowadzony dla zapobieżenia skutkom katastrof naturalnych (np. powodzi, suszy, itp.) lub awarii technicznych mającej znamiona klęski żywiołowej oraz w celu jej usunięcia. Katastrofę znacznych rozmiarów określa się jako kataklizm, skutki wtórne katastrof to choroby zakaźne, epidemie, zniszczenie środowiska naturalnego [1,2]. Pojęcie poważnej awarii oraz poważnej awarii przemysłowej wprowadziła ustawa z 27 kwietnia 2001r. Prawo ochrony środowiska. 6 kwietnia 2007 roku została uchwalona Ustawa o zarządzaniu kryzysowym[7](ustawa znosi ustawę o stanie klęski żywiołowej [8]), która określa sposób postępowania, gdy nie zachodzą przesłanki dla wprowadzenia jednego z konstytucyjnie uregulowanych stanów nadzwyczajnych (rozdział XI Konstytucji).Ustawa definiuje sytuację kryzysową jako, sytuację będącą następstwem zagrożenia $\mathrm{i}$ prowadząca $\mathrm{w}$ konsekwencji do zerwania lub znacznego naruszenia więzów społecznych przy równoczesnym poważnym zakłóceniu w funkcjonowaniu instytucji publicznych, jednak takim stopniu, że użyte środki niezbędne do zapewnienia lub przywrócenia bezpieczeństwa nie uzasadniają wprowadzenia żadnego ze stanów nadzwyczajnych o których mowa w art. 228 ust. 1 Konstytucji Rzeczypospolitej Polskiej.

\subsection{Zaopatrzenie w wode w sytuacjach kryzysowych}

W warunkach sytuacji kryzysowej woda do spożycia dostarczana do sieci wodociaggowej $\mathrm{w}$ ilościach niezbędnych powinna być $\mathrm{w}$ miarę możliwości pobierana $\mathrm{z}$ ujęć wody podziemnej, inne ujęcia $\mathrm{w}$ tych warunkach stają się ujęciami rezerwowymi. Wodociąg powinien posiadać możliwości [3]: odcięcia danych ujęć wody z operacyjną możliwością eksploatacji całego systemu lub jego fragmentów np. sieci wodociagowej, ujęcia wody, rurociagów tranzytowych, włączenia do pracy alternatywnych technologii uzdatniania wody (np. okresowe dawkowanie węgla aktywnego w postaci pylistej), zwiększenia dawek środka dezynfekującego, dostaw wody $\mathrm{z}$ pominięciem Zakładu Uzdatniania Wody. Uzdatnianie wody, dostarczanej $\mathrm{z}$ ujęć rezerwowych $\mathrm{w}$ ilości niezbędnej powinno być zapewnione $\mathrm{w}$ układach technologicznych przystosowanych do usuwania 
skażeń wody w stacjach uzdatniania wody, przewoźnych stacjach uzdatniania wody i filtrach specjalnych. Minimalne ciśnienie wody w sieci wodociagowej powinno wynosić dla wodociagu komunalnego 0,1 $\mathrm{MPa}$, dla wodociagu wiejskiego $0,06 \mathrm{MPa}$ [2]. W sytuacji unieruchomienia wodociagu oraz na terenach nie objętych siecią wodociagową, zaopatrzenie w wodę zapewnia się ze studni awaryjnych. W przypadku braku odpowiedniej ilości lub niekorzystnego rozmieszczenia studni awaryjnych należy przewidzieć dowóz wody cysternami i beczkowozami. Wodociagi oraz studnie awaryjne powinny być przygotowane na zasilanie w energię $\mathrm{z}$ zespołów prądotwórczych, ewentualnie wyposażone $\mathrm{W}$ zespoły prądotwórcze, których moc zapewni rozruch pomp i dostawę wody w okresie ograniczonych dostaw. Zapas paliwa powinien wystarczyć na $400 \mathrm{~h}$, jednak nie mniej niż na 200h, pracy zespołów prądotwórczych. Zapotrzebowanie na wodę w warunkach sytuacji kryzysowej należy określić dla wszystkich wodociagów miast i wsi nie objętych systemem wodociągowym. Powinno być ono zapewnione $\mathrm{z}$ wodociagów oraz studni awaryjnych, w razie potrzeby również z ujęć przemysłowych. Wyróżnia się dwa rodzaje zapotrzebowania na wodę w warunkach specjalnych[3,5]:

- niezbędna ilość wody (czas trwania kilka tygodni): ludność $15 \mathrm{dm}^{3} / \mathrm{os} \cdot \mathrm{d}$,

- minimalna ilość wody (czas trwania kilka dób): ludność $7,5 \mathrm{dm}^{3} / \mathrm{os} \cdot \mathrm{d}$.

\subsection{Ryzyko jako element zarządzania bezpieczeństwem $S Z W$}

Zarządzanie bezpieczeństwem SZW przeprowadza się poprzez analizę ryzyka, a w szczególności poprzez [4]: identyfikacje ryzyka, a w tym identyfikacja zagrożeń i skutków dla możliwych reprezentatywnych scenariuszy awaryjnych, ocenę (szacowanie ryzyka),zasady postępowania z ryzykiem, finansowanie ryzyka. Identyfikacja ryzyka polega głównie na analizie czynników ryzyka, ich źródeł, określenie tzw. słabych punktów oraz konsekwencji (skutków) ich występowania. Najczęściej analiza ta dotyczy zdarzeń niepożądanych, które mogą pojawić się $\mathrm{w}$ systemie z określonym prawdopodobieństwem „P” i wywołać określone straty „C”, co może skutkować utratą bezpieczeństwa SZW. Zdarzenia te mogą mieć charakter pojedynczy (incydentalny), może być to seria zdarzeń lub pojedyncze zdarzenie wywołujące serię następnych (tzw. efekt domina), co w konsekwencji może spowodować sytuacje kryzysową. Proces oceny ryzyka polega na wyznaczeniu (oszacowaniu) jego liczbowej wartości i porównaniu go z przyjętymi wartościami kryterialnymi[3]. Najczęściej spotykaną skalą poziomów ryzyka jest skala trójstopniowa wg zasady: 
ryzyko tolerowane $-\mathrm{r}_{\mathrm{T}}$, ryzyko kontrolowane $-\mathrm{r}_{\mathrm{K}}$, ryzyko nieakceptowane $\mathrm{r}_{\mathrm{N}}$. Przyjęcie wartości kryterialnych na poszczególnych poziomów skali zależy od wielu czynników, a w tym : ocen ekspertów jak również przyjętej metody szacowania ryzyka np. metody matrycowe $2,3,4$, lub 5 parametryczne [3]. Analizę wyników pod kątem możliwości zaistnienia sytuacji kryzysowej można przeprowadzić w oparciu o: rozkłady procentowy ryzyka wg . kategorii (rodzaju) ryzyka, rozkładu ryzyk nieakceptowanych, map ryzyka tj. rozkładu ryzyk tolerowanych, kontrolowanych i nieakceptowanych, oraz zakresu ryzyka akceptowanego jako sumy ryzyk tolerowanych i kontrolowanych, wyznaczenie tzw. wskaźników ryzyk $\left(\mathrm{Wr}_{\mathrm{ij}}\right)$ dla wszystkich rodzajów ryzyka. Ryzyko (r) jest funkcją trzech parametrów: prawdopodobieństwa $\mathrm{P}_{\mathrm{Si}}$ wystapienia i-tego reprezentatywnego scenariusza awaryjnego $\mathrm{S}_{\mathrm{i}}$, wielkości strat $\mathrm{C}_{\mathrm{Si}}$ wywołanych przez i-ty reprezentatywny scenariusz awaryjny $\mathrm{S}_{\mathrm{i}} \mathrm{i}$ ochrony konsumentów $\mathrm{O}_{\mathrm{Si}}$ przed i-tym reprezentatywnym scenariuszem awaryjnym $\mathrm{S}_{\mathrm{i},} \mathrm{r}=\mathrm{f}\left(\mathrm{P}_{\mathrm{Si}}, \mathrm{C}_{\mathrm{Si}}, \mathrm{O}_{\mathrm{Si}}\right)[4] \mathrm{wg}$ :

$r=\frac{P_{S i} \cdot C_{S i}}{O_{S i}}$

gdzie:

$\mathrm{S}_{\mathrm{i}}$ - i-ty reprezentatywny scenariusz awaryjny opisany jako ciag następujących po sobie zdarzeń niepożądanych,

$\mathrm{P}_{\mathrm{Si}^{-}}$waga punktowa związana $\mathrm{z}$ prawdopodobieństwem wystąpienia i-tego reprezentatywnego scenariusza awaryjnego $\mathrm{S}_{\mathrm{i}}$, przyjmowana wg. następującej skali: niski-1, średni-2, wysoki -3,

$\mathrm{C}_{\mathrm{Si}^{-}}$waga punktowa związana $\mathrm{z}$ wielkością strat wywołanych przez reprezentatywny scenariusz awaryjny $\mathrm{S}_{\mathrm{i}}$, przyjmowana wg. następującej skali: niski-1, średni-2, wysoki -3,

$\mathrm{O}_{\mathrm{Si}^{-}}$waga punktowa związana $\mathrm{z}$ ochroną SZW przed reprezentatywnym scenariuszem awaryjnym $S_{i}$. przyjmowany wg następującej skali: niski-1, średni-2, wysoki -3 .

W ten sposób otrzymuje się 27 możliwych wartości ryzyka. Wartości kryterialne dla poszczególnych poziomów skali przedstawiają się następująco: ryzyko tolerowane - $\mathrm{r}_{\mathrm{T}}$ : $[0,33 \div 2)$, ryzyko kontrolowane $\mathrm{r}_{\mathrm{K}}$ : $\left[2 \div 4\right.$ ), ryzyko nieakceptowane $-\mathrm{r}_{\mathrm{N}}:[4 \div 9]$. W ramach Badań Własnych przeprowadzonych w Katedrze Zaopatrzenia w Wodę i Odprowadzania Ścieków Politechniki Rzeszowskiej, zgodnie z katalogiem ryzyk, wykonano identyfikację ryzyka pięciu podsystemów SZW: $j=1$-ujmowania wody, $j=2$ uzdatniania wody, $j=3$-pompowania $\mathrm{i}$ magazynowania, $j=4$ - przesyłu $\mathrm{i} j=5$ dystrybucji wody), obliczono liczbę ryzyk mieszczących się w przyjętej 
skali ryzyka. $\mathrm{Na}$ tej podstawie obliczono wskaźnik ryzyka $\mathrm{Wr}_{\mathrm{ij}}$, co przedstawiono $\mathrm{w}$ tab.1 .

Tabela 1. Przykład analizy różnych rodzajów ryzyk.

\begin{tabular}{|c|c|c|c|c|c|c|c|c|c|}
\hline \multirow{2}{*}{$\mathrm{j}$} & \multicolumn{3}{|c|}{$\begin{array}{c}\text { Liczba ryzyk dla i -tego } \\
\text { poziomu }\end{array}$} & \multirow{2}{*}{$\mathrm{r}_{\mathrm{KTj}}$} & $\sum \mathrm{r}_{\mathrm{NKTj}}$ & $\mathrm{Wr}_{\mathrm{Tj}}$ & $\mathrm{Wr}_{\mathrm{Kj}}$ & $\mathrm{Wr}_{\mathrm{Aj}}$ & $\mathrm{Wr}_{\mathrm{Nj}}$ \\
\cline { 2 - 9 } & $\mathrm{i}=1-\mathrm{r}_{\mathrm{Tj}}$ & $\mathrm{i}=2-\mathrm{r}_{\mathrm{Kj}}$ & $\mathrm{i}=3-\mathrm{r}_{\mathrm{Nj}}$ & & & & & & \\
\hline $\mathrm{J}=1$ & 6 & 3 & 1 & 9 & 10 & 0,60 & 0,30 & 0,90 & 0,10 \\
\hline $\mathrm{J}=2$ & 4 & 3 & 2 & 7 & 9 & 0,44 & 0,33 & 0,78 & 0,22 \\
\hline $\mathrm{J}=3$ & 3 & 2 & 1 & 5 & 6 & 0,50 & 0,33 & 0,83 & 0,17 \\
\hline $\mathrm{J}=4$ & 5 & 3 & 2 & 8 & 10 & 0,50 & 0,30 & 0,80 & 0,20 \\
\hline $\mathrm{J}=5$ & 7 & 5 & 3 & 12 & 15 & 0,47 & 0,33 & 0,80 & 0,20 \\
\hline
\end{tabular}

Przyjęto następujące oznaczenia: $\mathrm{Wr}_{\mathrm{ij}}$ - wskaźnik ryzyka dla j-tego podsystemu $\mathrm{SZW}$ o i-tej skali, $\mathrm{Wr}_{\mathrm{Tj}} \mathrm{j}^{-}$wskaźnik ryzyka tolerowanego, $\mathrm{Wr}_{\mathrm{Kj}}$ wskaźnik ryzyka kontrolowanego, $\mathrm{Wr}_{\mathrm{Nj}^{-}}$wskaźnik ryzyka nieakceptowanego, $\mathrm{Wr}_{\mathrm{Aj}}$ - wskaźnik ryzyka akceptowalnego, $\mathrm{j}$ - podsystem SZW $(j=1,2,3,4,5)$, i-poszczególne poziomy ryzyka $\left(i=1\right.$ dla $r_{T}, i=2$ dla $r_{K}, i=3$ dla $\mathrm{r}_{\mathrm{N}}$ ). Poszczególne wartości wskaźników ryzyka $\mathrm{Wr}_{\mathrm{ij}}$ obliczono wg

- Wskaźnik ryzyka tolerowanego $\mathrm{Wr}_{\mathrm{Tj}}$ :

$\boldsymbol{W r}_{\boldsymbol{T}_{j}}=\frac{\boldsymbol{r}_{\boldsymbol{T} \boldsymbol{j}}}{\sum_{\boldsymbol{i}} \boldsymbol{r}_{\boldsymbol{i} \boldsymbol{j}}}$

- Wskaźnik ryzyka kontrolowanego $\mathrm{Wr}_{\mathrm{Kj}}$ :

$W r_{K}{ }_{j}=\frac{r_{K} j}{\sum_{i} r_{i j}}$

$\sum_{i} r_{i j}=r_{T j}+r_{K}+r_{N j}$

- Wskaźnik ryzyka nieakceptowanego $\mathrm{Wr}_{\mathrm{Nj}}$ :

$W r_{N_{j}}=\frac{r_{N j}}{\sum_{i} r_{i j}}$

- Wskaźnik ryzyka akceptowanego $\mathrm{Wr}_{\mathrm{Aj}}$

$W r_{A j}=\frac{r_{A j}}{\sum_{i} r_{r_{i j}}}$ 
$r_{\boldsymbol{A}}=\boldsymbol{r}_{\boldsymbol{T} j}+\boldsymbol{r}_{\boldsymbol{K} j}$

$\mathrm{r}_{\mathrm{Aj}}$ - ryzyko akceptowalne

\section{Podsumowanie}

Zarządzanie kryzysowe infrastrukturą krytyczną jest ważnym zagadnieniem i wymaga indywidualnej analizy dla każdego rodzaju infrastruktury, w tym dla systemów zaopatrzenia w wodę do spożycia. W sytuacji zaistnienia różnych sytuacji kryzysowych np. powodzi suszy, trzęsień ziemi, awarii, katastrofy technicznej, itp. zawsze istniej problem zaopatrzenia ludności w wodę zdatną do spożycia. Niejednokrotnie brak takiego zaopatrzenia może być powodem groźnych chorób a nawet epidemii. Również sam SZW może spowodować sytuację kryzysową w przypadku zaistnienia różnych scenariuszy zdarzeń niepożądanych, które mogą spowodować zawodność jego funkcjonowania, a w konsekwencji utratę bezpieczeństwa konsumentów wody. Dlatego tak istotne jest opracowanie planów awaryjnego zaopatrzenia w wodę do spożycia dla różnych sytuacjach kryzysowych, jak również szczegółowa analiza ryzyka możliwości wystąpienia zdarzeń niepożądanych w SZW, w celu opracowania kompleksowego programu zarządzania bezpieczeństwem tego systemu.

Praca naukowa finansowana ze środków na naukę w latach 2007-2010 jako projekt badawczy Nr N N523 376533 nt. "Opracowanie metodyki analizy i oceny ryzyka awarii systemów zaopatrzenia w wodę z uwzględnieniem bezpieczeństwa konsumentów

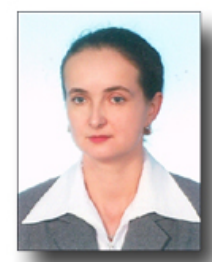

Dr. Eng. BARBARA TCHÓRZEWSKA-CIEŚLAK was graduated from Rzeszow University of Technology, Faculty of Civil and Environmental Engineering, in 1997. In 2001 she obtained a doctorate degree in Engineering at Cracow University of Technology, Faculty of Environmental Engineering. She is currently working as an assistant professor at Rzeszow University of Technology, Department of Water Supply and Sewage Systems. Specialization - water supply systems, reliability and safety analyses of municipal systems. 